\title{
DESAIN EKSPERIMENTAL FAKTORIAL UNTUK PENENTUAN FAKTOR PALING BERPENGARUH PADA PROSES PULPING ORGANOSOLV BERBAHAN BAKU LIMBAH DAUN NANAS
}

\author{
Glenn Mochamad Rayhan' ${ }^{1)}$, Salsabila Fachrina ${ }^{1)}$, Rizka Amalia ${ }^{*, 2)}$ \\ ${ }^{1)}$ Program Studi D-III Teknologi Kimia, Sekolah Vokasi, Universitas Diponegoro \\ Jl. Prof. Soedarto, SH, Kampus Undip Tembalang, Semarang, Indonesia 50275 \\ 2) Program Studi Sarjana Terapan Teknologi Rekayasa Kimia Industri, Sekolah Vokasi, Universitas Diponegoro \\ Jl. Prof. Soedarto, SH, Kampus Undip Tembalang, Semarang, Indonesia 50275
}

\begin{abstract}
Paper production has been identified with industries that destroy forests (deforestation). Utilizing alternative wood substitute raw materials, such as pineapple leaves can be one solution to the problem. Pineapple plants can produce more than 70 leaves with cellulose content in the leaves which reaches 69.5$71.5 \%$, so it has the potential to be used as raw material for paper. The organosolv process was chosen as a pulp manufacturing process because it produces high purity in the byproducts (lignin and hemicellulose), high pulp yield, easy recovery of black liquor and no sulfur element, making it safer for the environment. This study aims to determine the most influential factors in the organosolv pulping process with a factorial experimental design method 23. Variables used include solvent types (ethanol and acetic acid), pulp cooking time (60 minutes and 110 minutes) and types of leaf dryness (wet leaves) and dried leaves). From the results of the analysis, the most influential factor in the organosolv pulping process is the type of solvent (ethanol). Optimal operating conditions were obtained for solvent ethanol, cooking time of 60 minutes with wet leaves, where cellulose content was $96.31 \%$ and lignin content decreased by $17.80 \%$ in dry pulp.
\end{abstract}

Keywords: paper; pulping; organosolv; pineapple; experiment design

\section{PENDAHULUAN}

Industri kertas adalah salah satu industri terbesar di dunia dan akan terus meningkat kebutuhannya hingga $2-3 \%$ pertahun, akibatnya kebutuhan kayu gelondongan setiap tahunnya juga meningkat. Namun, produksi kertas selama ini sering diidentikkan dengan industri yang merusak hutan (deforestasi). Pemanfaatkan bahan baku alternatif pengganti kayu dapat menjadi solusi untuk permasalahan tersebut. Pemerintah melalui Badan Penelitian dan Pengembangan Industri (BPPI) mendorong peningkatan produksi pulp dan kertas dari bahan baku non kayu, salah satunya berasal dari limbah hasil pertanian [1].

Indonesia memiliki kekayaan sumber hayati serat alam, dan salah satu yang berpotensi untuk dikembangkan adalah serat daun nanas. Data dari Badan Pusat Statistik melaporkan jumlah produksi nanas di Indonesia pada tahun 2013 mencapai 1.558.196 ton. Di satu sisi, peningkatan metode budidaya tanaman nanas dapat meningkatkan produksi buah, tetapi disisi lain memberikan dampak pada semakin bertambahnya limbah daun dan tangkai tanaman nanas. Kebanyakan masyarakat Indonesia hanya mengetahui tanaman nanas ini dengan buahnya saja, tanpa terpikirkan limbah daun nanas tersebut dapat dimanfaatkan sebagai olahan alternatif pembuatan pulp karena kandungan selulosanya yang cukup tinggi, yaitu sebesar 69,5$71,5 \%$ [2].

Proses pembuatan pulp dapat dilakukan secara mekanik, kimia, biologi, maupun semikimia.
Dari beberapa proses tersebut, proses pulping kimia lebih sering digunakan, terutama proses kraft dengan solvent $\mathrm{NaOH}$ [3] Namun, proses kraft memiliki keterbatasan yakni rendemen yang dihasilkan rendah dan bahan-bahan yang digunakan tidak ramah lingkungan [4].

Proses organosolv merupakan salah satu proses pembuatan pulp secara kimiawi dengan menggunakan bahan kimia organik seperti metanol, etanol, aseton, asam asetat, dan lain-lain. Pada penelitian ini, proses organosolv dipilih karena prosesnya yang lebih ramah lingkungan. Kelebihan proses organosolv antara lain: menghasilkan kemurnian yang tinggi pada hasil samping (lignin dan hemiselulosa), rendemen pulp tinggi, recovery larutan sisa pulping (black liquor) mudah dan tanpa unsur sulfur, sehingga lebih aman terhadap lingkungan, [5]. Proses pulping organosolv dapat dilakukan dengan menggunakan bahan kimia organik seperti, aseton, etanol, metahol, asam formiat, asam asetat dll. [6]. Proses pulping dengan menggunakan larutan pemasak alkohol disebut proses alcell (alcohol cellulose) sedangkan jika bahan pemasak menggunakan asam asetat disebut dengan proses acetosolv / acetocell. Asam asetat diketahui dapat memisahkan lignin, sellulosa dan hemisellulosa secara selektif dari berbagai biomassa seperti ampas tebu [7], kayu lunak dan kayu keras. Lignin juga dapat dipisahkan dari kayu dengan menggunakan etanol sebagai solvent. Pada range konsentrasi sedang, etanol dapat mendelignifikasi kayu baik pada softwood maupun hardwood [8]. 
Proses alcell telah dikembangkan di pabrik percontohan pada berbagai negara, seperti di Kanada dan Amerika Serikat. Sedangkan proses acetocell mulai dikembangkan pada beberapa pabrik di Jerman pada tahun 1990-an. Proses alcell yang sudah beroperasi pada pabrik di Kanada terbukti mampu menghasilkan pulp yang setara dengan kekuatan pulp kraft serta menghasilkan rendemen dan recovery yang tinggi [9]. Berdasarkan hal tersebut, pada penelitian ini dilakukan pembuatan pulp dengan membandingkan jenis solvent : etanol dan asam asetat.

Penelitian pulping organosolv dengan larutan pemasak etanol $64,1 \%$ pada suhu $120^{\circ} \mathrm{C}$ selama 155 menit oleh Muis menghasilkan pulp dengan kadar selulosa 83,3\% [10]. Penelitian Kirci dan Akgul pada proses delignifikasi kepingan kayu poplar menggunakan etanol $40 \%$ pada suhu $180^{\circ} \mathrm{C}$ dan waktu pemasakan 150 menit, perolehan selulosanya sebesar 95,8\% [11]. Sedangkan kondisi optimal proses pulping organosolv dengan larutan asam asetat $90 \%$ yang dilakukan oleh Wibisono dkk. pada suhu proses $100^{\circ} \mathrm{C}$ selama 1 jam, menghasilkan pulp dengan kadar selulosa 84,6\% [12]. Menurut Nurhidayani dan Tamboesai, suhu pemasakan $118^{\circ} \mathrm{C}$ merupakan suhu optimum, karena pada suhu tersebut lignin sudah terdegradasi dengan baik [13].

Beberapa faktor yang dapat mempengaruhi proses pulping antara lain: jenis dan konsentrasi solvent, rasio biomassa: solvent, suhu, waktu pemasakan, jenis serta ukuran biomassa. Penelitian ini bertujuan untuk mencari faktor paling berpengaruh pada proses pulping organosolv limbah daun nanas meliputi jenis solvent (etanol dan asam asetat), waktu pemasakan pulp (60 menit dan 110 menit) dan jenis kekeringan daun (daun basah dan daun kering). Pengolahan dan intepretasi data dalam penelitian ini dilakukan dengan desain eksperimental $2^{3}$ untuk mendapatkan data yang berguna dalam menentukan parameter yang paling berpengaruh.

\section{METODE PENELITIAN}

\section{Alat dan Bahan}

Bahan-bahan yang digunakan dalam proses pulping antara lain: daun nanas, asam asetat, etanol dan aquadest. Sedangkan untuk analisis digunakan $\mathrm{NaOH}, \mathrm{H}_{2} \mathrm{SO}_{4}$ dan aquadest. Semua bahan kimia diperoleh dari Toko Kimia Indrasari, Semarang. Proses pulping dilakukan dalam suatu alat digester tertutup, kapasitas $5 \mathrm{~kg}$ yang beroperasi pada suhu $118^{\circ} \mathrm{C}$ dan tekanan awal 1 atm (tekanan dapat berubah seiring perubahan temperatur). Sedangkan alat yang digunakan adalah alat digester seperti yang ditunjukkan pada Gambar 1.

\section{Variabel Tetap \\ Temperatur pemasakan $: 118^{\circ} \mathrm{C}$ \\ Jenis Biomassa : daun nanas \\ Berat biomassa $\quad: 400$ gram \\ Konsentrasi etanol : $70 \%$}

Konsentrasi asam asetat : $75 \%$

Rasio larutan pemasak dengan bahan baku : $10: 1$

\section{Variabel Berubah}

Solvent (S)

Waktu pulping (t)

: Etanol

Asam asetat

: 110 menit

60 menit

Kekeringan Daun (D)

Variabel Terikat

: Daun kering

Daun basah

$(+)$

$(-)$

$(+)$

$(-)$

$(+)$

$(-)$
Kadar Selulosa (\%)

Penurunan kadar lignin $(\%)$

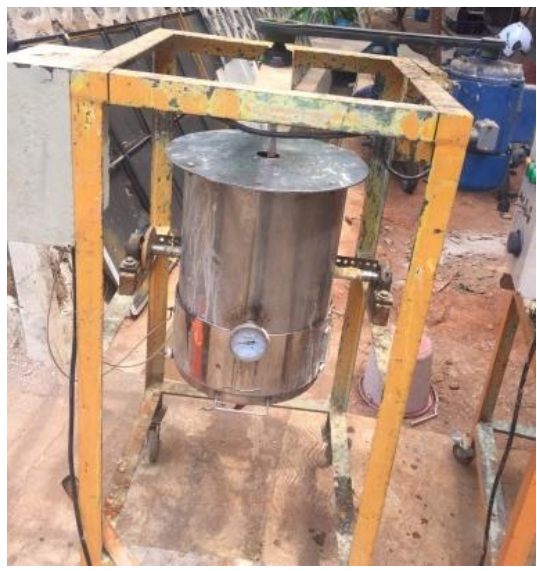

Gambar 1. Alat Digester

\section{Prosedur Pulping Organosolv}

Daun nanas (kering (-), basah (+)) yang sudah dihaluskan dengan blender ditimbang sebanyak 400 gr. Kemudian ditambahkan larutan pemasak (etanol (+), asam asetat (-)). Sampel dimasak pada suhu $118^{\circ} \mathrm{C}$ dengan waktu 60 menit (-), dan 110 menit (+). Setelah pemasakan selesai pulp dicuci dengan air sampai filtratnya jernih dan disaring dengan kertas saring. Pulp yang didapat selanjutnya dikeringkan dalam oven pada suhu $105^{\circ} \mathrm{C}$ selama 1 jam dan hasil yang diperoleh ditimbang.

\section{Prosedur Analisis}

Pulp yang dihasilkan selanjutnya dianalisis untuk mengetahui kadar selulosa (SNI 8400:2017) [14] dan lignin (SNI 8429:2017)[15].

\section{Analisis Desain Eksperimental}

Pengolahan dan intepretasi data dalam penelitian ini dilakukan dengan desain eksperimental $2^{3}$ untuk mendapatkan data yang berguna dalam menentukan parameter yang paling berpengaruh dalam proses pulping organosolv. Desain eksperimental merupakan salah satu cara pengolahan data secara statistik yang sering digunakan dibandingkan dengan metode konvensional lainnya. Keunggulan dari metode desain eksperimen antara lain: (i) memerlukan lebih sedikit variabel percobaan; (ii) kondisi optimal yang diperoleh lebih 
tepat karena mencakup faktor interaksi; dan (iii) kesimpulan lebih pasti karena didukung oleh metode perhitungan statistik sederhana.

\section{HASIL DAN PEMBAHASAN}

Banyak penelitian menggunakan metode Desain Eskperimental dalam menentukan factor paling berpengaruh pada berbagai proses termasuk dalam proses ekstraksi zingiberene jahe [16-17]. Dalam penelitian ini, metode desain eksperimental dirancang dan dianalisis untuk membuktikan hipotesis. Dalam desain eksperimental, masingmasing variabel yang diuji ditentukan pada beberapa nilai; dalam penelitian ini ditentukan dua nilai pada tiga variabel independen $\left(2^{3}\right)$. Kombinasi variabel independen memungkinkan data yang diperoleh untuk membantu penarikan kesimpulan dengan menggunakan metode statistik. Hasil pengolahan data dengan desain faktorial dapat dilihat pada Tabel 1 dan Tabel 2.
Pembuatan pulp dikatakan berhasil apabila diperoleh pulp dengan penurunan kadar lignin yang besar sehingga dihasilkan peningkatan persen kadar selulosa pulp hasil delignifikasi [18]. Pada Tabel 1 dan Tabel 2 dapat dilihat bahwa hasil analisis desain eksperimental proses pulping organosolv dengan bahan baku limbah daun nanas terhadap perolehan kadar selulosa dan penurunan kadar lignin saling berkesesuaian satu sama lain, dimana didapatkan hasil variabel yang paling berpengaruh adalah jenis solvent, dengan jenis solvent yang paling optimal adalah etanol.

Pada penelitian kami, kondisi operasi optimal diperoleh pada jenis solvent etanol 70\%, waktu pemasakan 60 menit dan daun basah, dengan perolehan kadar selulosa sebesar 96,31\% dan penurunan kadar lignin sebesar 17,80\%.

Tabel 1 Analisis penelitian eksperimental terhadap kadar selulosa pulp

\begin{tabular}{ccccccccccc}
\hline No & $\mathbf{S}$ & $\mathbf{t}$ & $\mathbf{D}$ & $\begin{array}{c}\text { Kadar } \\
\text { Selulosa } \\
(\boldsymbol{\%})\end{array}$ & $\mathbf{( 1 )}$ & $\mathbf{( 2 )}$ & $\mathbf{( 3 )}$ & Pembagi & Efek & Hasil \\
\hline 1 & - & - & - & 92.86 & 189.17 & 354.34 & 658.43 & 8 & rata-rata & 82.30 \\
2 & + & - & - & 96.31 & 165.17 & 304.09 & -17.15 & 4 & $\mathrm{~S}$ & -4.29 \\
3 & - & + & - & 84 & 156.98 & 0.62 & -33.87 & 4 & t & -8.47 \\
4 & + & + & - & 81.17 & 147.11 & -17.77 & -6.45 & 4 & St & -1.61 \\
5 & - & - & + & 82.89 & 3.45 & -24 & -50.25 & 4 & $\mathrm{D}$ & -12.56 \\
6 & + & - & + & 74.09 & -2.83 & -9.87 & -18.39 & 4 & SD & -4.59 \\
7 & - & + & + & 78.04 & -8.8 & -6.28 & 14.13 & 4 & tD & 3.53 \\
8 & + & + & + & 69.07 & -8.97 & -0.17 & 6.11 & 4 & StD & 1.53 \\
\hline
\end{tabular}

Tabel 2 Analisis penelitian eksperimental terhadap penurunan kadar lignin

\begin{tabular}{|c|c|c|c|c|c|c|c|c|c|c|}
\hline No & $\mathbf{S}$ & $\mathbf{t}$ & D & $\begin{array}{c}\text { enuruna } \\
\text { Kadar } \\
\text { Lignin } \\
(\%)\end{array}$ & (1) & (2) & (3) & Pembagi & Efek & Hasil \\
\hline 1 & - & - & - & 0,88 & 18,68 & 15,02 & 61,64 & 8 & rata-rata & 7,70 \\
\hline 2 & + & - & - & 17,80 & $-3,657$ & 46,61 & 34,40 & 4 & $\mathrm{~S}$ & 8,60 \\
\hline 3 & - & + & - & $-2,83$ & 26,81 & 18,92 & $-29,35$ & 4 & $\mathrm{t}$ & $-7,33$ \\
\hline 4 & + & + & - & $-0,82$ & 19,80 & 15,47 & $-15,06$ & 4 & St & $-3,76$ \\
\hline 5 & - & - & + & 9,50 & 16,91 & $-22,34$ & 31,59 & 4 & $\mathrm{D}$ & 7,89 \\
\hline 6 & + & - & + & 17,31 & 2,004 & $-7,009$ & $-3,44$ & 4 & SD & $-0,86$ \\
\hline 7 & - & + & + & 6,06 & 7,81 & $-14,91$ & 15,33 & 4 & $\mathrm{tD}$ & 3,83 \\
\hline 8 & + & + & + & 13,73 & 7,66 & $-0,14$ & 14,76 & 4 & StD & 3,69 \\
\hline
\end{tabular}

Penggunaan jenis solvent etanol lebih baik dibandingkan dengan asam asetat ditunjukkan dengan perolehan kadar selulosa yang lebih tinggi. Hal tersebut bisa dijelaskan karena terjadinya hidrolisis secara kimia dalam pembuatan pulp dalam suasana asam merupakan reaksi degradasi terhadap glikosida yang terikat secara glikosidik di-, oligo dan polisakarida, sehingga rantai panjang selulosa akan menjadi pendek dan senyawa hasil degradasi seperti asam-asam hidroksi akan larut saat pencucian dan kadar selulosa akan menjadi rendah [19]. Penelitian Artati [4] melaporkan bahwa bertambahnya konsentrasi asam asetat menghasilkan peningkatan kadar selulosa. Kenaikan tersebut karena lignin sebagai pengikat selulosa akan terpisah sehingga kadar selulosa semakin besar.

Pada percobaan dengan penambahan etanol, daun nanas basah, dan waktu pulping 60 menit didapatkan penurunan kadar lignin terbesar yaitu 17,80\%. Menurut Vasquez [20] dengan bertambahnya waktu pemasakan lignin yang terpisah dari biomassa semakin banyak, hal ini menyebabkan kadar lignin di dalam pulp semakin berkurang. Namun pemasakan yang lebih lama, dapat 
menyebabkan kadar lignin dalam pulp cenderung untuk meningkat kembali. Menurut Shere B. Noris [21], dengan berkurangnya konsentrasi larutan pemasak, lignin yang sudah tersisihkan dari raw pulp akan kembali menyatu dengan raw pulp dan sukar untuk memisahkannya lagi, sehingga kandungan lignin dapat meningkat. Waktu optimal yang dibutuhkan untuk delignifikasi adalah 60-120 menit, persen perolehan pulp tidak meningkat setelah pemasakan 120 menit.

\section{KESIMPULAN}

Hasil analisis pengaruh parameter proses (jenis solvent, waktu pemasakan, dan tingkat kekeringan daun) terhadap proses pulping organosolv berbahan dasar limbah daun nanas telah dilakukan dan disimpulkan bahwa faktor yang paling berpengaruh adalah jenis solven. Kondisi operasi optimal diperoleh pada jenis solvent etanol $70 \%$, waktu pemasakan 60 menit, suhu pemasakan $118^{\circ} \mathrm{C}$ dan tekanan awal 1 atm dengan bahan daun basah, didapatkan pulp dengan kadar selulosa sebesar 96,31 \% serta penurunan kadar lignin sebesar $17,80 \%$.

\section{UCAPAN TERIMA KASIH}

Ucapan terima kasih dari peneliti kepada Program Studi dan Laboratorium DIII Teknik Kimia dan Sarjana Terapan Teknologi Rekayasa Kimia Industri, Sekolah Vokasi Unniversitas Diponegoro atas dukungannya dalam kelancaran kegiatan penelitian ini.

\section{DAFTAR PUSTAKA}

1. Kementrian Perindustrian. 2017. Produksi Pulp dan Kertas Manfaatkan Bahan Non Kayu, Berita Industri.

2. H. Onggo, \& T. Jovita, 2005, Pengaruh Sodium Hidroksida dan Hidrogen Peroksida Terhadap Rendemen dan warna Pulp Dari Serat Nanas , Jurnal Ilmu dan Teknologi Kayu Tropis, 3 (1), 37-43. [Online].

3. Jalaluddin, S. Rizal, 2005, Pembuatan Pulp dari Jerami Padi dengan Menggunakan Natrium Hidroksida, Jurnal Sistem Teknik Industri, 6(5), 53-56. [Online].

4. E.K. Artati, A. Effendi, T. Haryanto, Pengaruh Konsentrasi Larutan Pemasak Pada Proses Delignifikasi Eceng Gondok Dengan Proses Organosolv. Ekuilibrium. 8 (1). 25 - 28 . [Online].

5. P. Coniwanti, S. Novalina, \& I.K.Putri, 2009, Pengaruh Konsentrasi Larutan Etanol, Temperatur dan Waktu Pemasakan pada Pembuatan Pulp Eceng Gondok Melalui Proses Organosolv, Jurnal Teknik Kimia, 16 (4), 3441. [Online].

6. L. Jimenez, J.C. Garcia, I. Perez, J. Ariza \& F. Lopez, 2001, Acetone Pulping of Wheat Straw. Influence of Cooking and Beating Conditions on The Resulting Paper Sheets, American Chemical Society. 40 (26), 6201-6206. [Online].

7. A. Gunawan, D.E. Sihotang, \& M.Y. Thoha, 2012, Pengaruh Waktu Pemasakan dan Volume Larutan Pemasak Terhadap Viskositas Pulp Dari Ampas Tebu, Jurnal Teknik Kimia. 2 (18), 1-8. [Online].

8. T.N. Kleinert, 1974, Organosolvent pulping with aqueous alcohol, TAPPI. 57 (8), 99-102.

9. E.K. Pye, \& J.H. Lora, 1991, The Alcell process. A proven alternative to kraft pulping, TAPPI, 74(3): p. 113-118.

10. L. Muis, 2013. Pulpinisasi Jerami Padi menggunakan Metode Organosolv, Jurnal Sainmatika, 7(1), 1-6.

11. H. Kirci, \& M. Akgul, 2002, Production of Dissolving Pulp from Poplar Wood by EthanolWater Process, Turk. J. Agric. For, 26:239-245.

12. I. Wibisono, H. Leonardo, Antaresti, Aylianawati, 2011, Pembuatan Pulp dari Alang-Alang, Widya Teknik, 10(1) : 11-20.

13. Nurhidayani, \& E.M. Tamboesai, Perbandingan Metode Sulfat (Kraft) dan Organosolv dalam Pembuatan Pulp Berbahan Baku Daun Nanas (Ananas comusus Meer), Skripsi. Tidak Diterbitkan. Fakultas MIPA. Universitas Riau: Pekanbaru.

14. SNI 8400:2017. Selulosa alfa, beta dan gama dalam pulp (T $203 \mathrm{~cm}-09$, IDT). Diakses pada 24 Januari $2020 \quad$ dari http://sispk.bsn.go.id/SNI/DetailSNI/11379

15. SNI 8429:2017. Lignin tidak larut asam dalam kayu dan pulp (T 222 om-15, IDT). Diakses pada 24 Januari 2020 dari http://sispk.bsn.go.id/SNI/DetailSNI/11513

16. D. Handayani, R. Amalia, M.E. Yulianto, I. Hartati, \& Murni, 2018, Determination of Influential Factors During Enzymatic Extraction of Ginger Oil Using Immobile Isolated Cow Rumen Enzymes, International Journal of Technology. 3, 455-463. [Online].

17. G. Anggista, I.T. Pangestu, D. Handayani, M.E Yulianto, S. Kusuma, 2019, Penentuan Faktor Berpengaruh Pada Ekstraksi Rimpang Jahe Menggunakan Extraktor Berpengaduk, Gema Teknologi. 20(3), 80-84. [Online].

18. T.K. Dewi, A. Wulandari, \& Romy, 2009, Pengaruh Temperatur, Lama Pemasakan, dan Konsentrasi Etanol Pada Pembuatan Pulp Berbahan Baku Jerami Padi dengan Larutan Pemasak NaOH-Etanol, Jurnal Teknik Kimia. 16 (3), 11-20. [Online].

19. D. Fengel, \& G. Wegener, 1995. Kimia Kayu dan Reaksi-Reaksi Ultrasruktur (terjemahan). Hardjono Sastrohamidjojo, penerjemah. Yogyakarta. Universitas Gajah Mada Press.

20. Duke, J. Allan, Vasquez, Rodolfo, 1994, Amazonian Ethnobotanical Dictionary, Iquitos Peru : CRC Press. 
21. Shere B. Noris, 1959, Lignin dan Kadar Metoksil dari Beberapa Bahan Baku untuk Pulp. Bandung : Balai Penelitian Pulp, Balai Besar Selulosa. 